\title{
Chaperone-dependent gene expression of organic solvent-tolerant lipase from Pseudomonas aeruginosa strain S5.
}

\begin{abstract}
The gene coding for the intracellular organic solvent-tolerant lipase of Pseudomonas aeruginosa strain S5 was isolated from a genomic DNA library and cloned into p RSET. The cloned sequence included two open reading frames (ORF) of $1575 \mathrm{bp}$ for the first ORF (ORF1), and $582 \mathrm{bp}$ for the second ORF (ORF2). The ORF2, known as chaperone, plays an important role in the expression of the S5 gene. The ORF2 is located downstream of lipase gene, and functions as the act gene for ORF1. The conserved pentapeptide, Gly-X-Ser-XGly, is located in the ORF1. A sequence coding for a catalytic triad that resembles that of a serine protease, consisting of serine, histidine, and aspartic acid or glutamic acid residues, was present in the lipase gene. Expression of the S5 lipase gene in E. coli resulted in a 100fold increase in enzyme activity $9 \mathrm{~h}$ after induction with $0.75 \mathrm{mM}$ IPTG. The recombinant protein revealed a size of $60 \mathrm{kDa}$ on SDS-PAGE. The Lip S5 gene was stable in the presence of $25 \%(\mathrm{v} / \mathrm{v}) \mathrm{n}$-dodecane and $\mathrm{n}$-tetradecane after $2 \mathrm{~h}$ incubation at $378 \mathrm{C}$.
\end{abstract}

Keyword: Organic solvent-tolerant lipase; Chaperone; Pseudomonas aeruginosa; Shot-gun cloning; Expression; Phylogenetic tree analysis. 